\title{
Kualitas Fisik dan Organoleptik Bakso Berbahan Dasar Daging Ayam Broiler yang Diberi Pakan dengan Suplementasi Tepung Purslane (Portulaca oleraceae)
}

\author{
L. R. Kartikasari*, B. S. Hertanto, A. S. D. Pamungkas, I. S. Saputri, A. M. P. Nuhriawangsa \\ Program Studi Peternakan, Fakultas Pertanian, Universitas Sebelas Maret, Surakarta, Indonesia 57126
}

\begin{abstract}
ABSTRAK
Penelitian ini bertujuan untuk mengevaluasi kualitas fisik dan organoleptik bakso berbahan dasar daging ayam yang berasal dari ayam broiler yang diberi pakan dengan suplementasi tepung purslane sebagai sumber asam lemak omega-3. Materi penelitian menggunakan 30 sampel daging paha atas ayam broiler strain Cobb yang dipanen pada umur 42 hari dengan perlakuan ransum basal yang mengandung 1,5\% minyak ikan sarden dan suplementasi tepung purslane dengan level yang berbeda. Perlakuan penelitian ini terdiri dari bakso daging ayam yang berasal dari ayam broiler yang diberi pakan dengan suplementasi tepung purslane $0 \%(\mathrm{P} 1) ; 6 \%(\mathrm{P} 2), 12 \%(\mathrm{P} 3)$, dan $18 \%(\mathrm{P} 4)$. Enam ekor ayam dari masing-masing perlakuan diproses menjadi karkas dan selanjutnya diambil daging paha atas (thigh) dikumpulkan untuk pembuatan bakso. Pengujian kualitas bakso meliputi pengujian kualitas fisik dan organoleptik. Data dianalisis menggunakan analisis variance (ANOVA) yang dilanjutkan dengan uji Tukey's Test. Hasil penelitian menunjukkan penggunaan daging ayam yang diberi pakan mengandung tepung purslane sampai level $18 \%$ tidak memberikan perbedaan terhadap kualitas fisik bakso ( $\mathrm{pH}$, daya ikat air, susut masak), kualitas organoleptik dan penerimaan konsumen, dibandingkan bakso dari daging ayam tanpa pemberian tepung purslane. Disimpulkan bahwa bakso yang mengandung daging ayam yang diberi pakan dengan suplementasi tepung purslane sampai level $18 \%$ dapat diaplikasikan pada pembuatan bakso tanpa merubah kualitas fisik dan organoleptik bakso.
\end{abstract}

Kata kunci: Bakso ayam, Kualitas fisik, Kualitas organoleptik, Pakan, Tepung purslane

\section{Physical and Sensory Quality of Meatball Produced from Broiler Chickens Fed Diets Supplemented with Purslane Meal (Portulaca oleraceae)}

\begin{abstract}
This study was aimed to evaluate physical and sensory quality of chicken meatball produced from broiler chicken fed diets supplemented with purslane meal as omega-3 fatty acid source. The material used was 30 Cobb strain chicken thigh fed a basal diet containing $1.5 \%$ fish oil and different levels of purslane meal for 42 days. The treatments were chicken meatballs fed diets containing 0; 6; 12; and 18\%. Six chickens for each treatment were processed as carcass and thigh meat samples were collected for producing meatballs. The meatballs were analysed for physical and sensory qualities. The data were analysed using analysis of variance (ANOVA). Differences between treatment means were further analysed using Tukey's test. The results showed that the use of meat of chicken fed diets containing purslane meal up to a level of $18 \%$ did not cause differences in physical quality ( $\mathrm{pH}$, water holding capacity, cooking loss, tenderness), sensory quality and consumer acceptance, compared to meatball as produced from chickens fed diets without purslane meal supplementation. The conclusion of this research was meatballs containing chicken meat fed diets enriched with purslane meal up to a level of $18 \%$ can be applied for meatball processing without changing the physical and sensory quality of broiler meatballs.
\end{abstract}

Keywords: Chicken meatballs, Physical quality, Sensory quality, Diets, Purslane meal

\section{PENDAHULUAN}

Daging ayam broiler merupakan bahan pangan yang relatif populer di masyarakat. Daging ayam broiler dapat diolah dalam berbagai jenis produk yang menarik dengan tujuan memperpanjang masa simpan dan meningkatkan minat masyarakat untuk mengkonsumsi daging ayam broiler, sebagai contoh dengan dibuat produk bakso. Bakso adalah produk olahan daging yang dicampur dengan pati dan bumbubumbu yang berbentuk bulat dan dimatangkan (BSN, 2014). Bakso yang ada di pasaran umumnya merupakan bakso yang terbuat dari daging sapi tetapi pembuatan bakso daging ayam dapat menjadi alternatif.

Daging ayam broiler sebagai bahan produk olahan bakso selain bernilai gizi tinggi juga berpotensi untuk ditingkatkan kandungan komponen-komponen

\footnotetext{
*Penulis korespondensi: Lilik Retna Kartikasari

Alamat: Program Studi Peternakan, Fakultas Pertanian, Universitas Sebelas Maret, J1. Ir. Sutami No. 36A Surakarta 57126, Indonesia Email: lilikretna@staff.uns.ac.id
}

aktifnya yang mempunyai efek kesehatan. Upaya tersebut antara lain dengan meningkatkan kandungan asam lemak tidak jenuh ganda omega-3. Asam lemak omega-3 berperan dalam kesehatan, seperti mencegah penyakit kardiovaskuler, perkembangan fungsi syaraf dan otak, dan menurunkan resiko diabetes. Kandungan asam lemak omega-3 dalam karkas atau daging dapat ditingkatkan melalui manipulasi pakan (Kartikasari et al., 2012).

Sumber asam lemak omega-3 yang dapat digunakan pada pakan ayam broiler yaitu tepung ikan atau minyak ikan, akan tetapi penggunaan asam lemak omega-3 dari sumber laut ini dapat menurunkan kualitas organoleptik produk daging seperti terjadinya off flavor (Bou et al., 2005). Penurunan kualitas tersebut kemungkinan karena adanya trimetilamin. Menurut Hasanah (2017) trimetilamin adalah senyawa yang menimbulkan bau amis yang tidak enak. Oleh karena itu, diperlukan sumber asam lemak omega-3 alternatif. Sumber alternatif yang dapat digunakan adalah tanaman kaya akan asam lemak omega-3 
(alpha-linolenic acid) sebagai contoh tanaman purslane (Almatsier, 2006). Daun tanaman purslane mengandung asam lemak n-3 yang tinggi (Aydin and Dogan, 2010), $\beta$-carotene, folic acid, vitamin C, kalium, kalsium dan berfungsi sebagai anti oksidan (Irawan et al., 2003). Tanaman purslane juga mengandung protein $(2-2,5 \%)$, asam linoleat yang mampu menurunkan kolesterol darah, vitamin A, B, dan C (Raharjo, 2011), juga kaya akan lemak dan serat kasar (Lishianawati, 2017).

Penggunaan tepung purslane pada pakan tidak menurunkan kualitas fisik daging ayam. Kualitas fisik bakso yang baik dapat mempengaruhi penerimaan konsumen. Kualitas fisik bakso daging ayam dapat dilihat dengan pengukuran $\mathrm{pH}$, daya ikat air, susut masak, dan keempukan bakso. Kartikasari et al. (2018) melaporkan bahwa pakan ayam broiler yang diperkaya dengan tepung purslane (Portulaca oleracea) hingga level $12 \%$ tidak mengubah kualitas daging termasuk pH, WHC, keempukan, kadar air dan kadar lemak.

Sejauh ini penggunaan tanaman purslane sebagai sumber asam lemak omega-3 terkait dengan kualitas fisik dan organoleptik bakso daging ayam broiler belum banyak dilaporkan. Oleh karena itu penelitian dilakukan untuk mengevaluasi kualitas fisik, organoleptik dan peneriman bakso daging ayam broiler dengan suplementasi tepung purslane (Portulaca oleraceae) sebagai sumber asam lemak omega-3.

\section{MATERI DAN METODE}

\section{Alat Penelitian}

Pengujian kualitas fisik menggunakan alat terdiri atas $\mathrm{pH}$ meter, mangkok plastik, cawan porselin, oven gas, pemberat $35 \mathrm{~kg}$, timbangan digital, timbangan analitik, penggaris, mika, spidol, kertas millimeter, waterbath, plastik klip dan penetrometer. Penetrometer digunakan untuk mengukur tingkat keempukan bakso. Alat yang digunakan untuk pembuatan bakso dan kualitas organoleptik bakso daging ayam meliputi kompor, panci, meat grinder, chopper, pisau, container, telenan, timbangan analitik, plastic clip, freezer, label, nampan, piring, tissue, sendok, peniris bakso, plastik alas meja, plastik pembungkus bakso, lakban, gunting, masker, consent form, lembar kerja, bain marie, kertas kuisioner, garpu plastik, original cracker, aqua, alat tulis, cup aluminium, aluminium foil dan sarung tangan plastik.

\section{Bahan Penelitian}

Bahan baku dalam penelitian ini adalah daging ayam broiler yang diberi pakan basal dengan suplementasi tepung purslane 0, 6, 12 dan $18 \%$. Kandungan nutrien pakan basal terdiri dari ME 3317.73 $\mathrm{Kcal} / \mathrm{kg}$, protein kasar 21,3\%, dan lemak $2.94 \%$. Bahan lain adalah es, tepung tapioka, lada, garam, MSG, putih telur dan bawang putih.

\section{Desain Penelitian}

Desain penelitian yang digunakan dalam penelitian ini adalah rancangan acak lengkap (RAL) pola searah. Bakso yang digunakan berasal dari daging ayam broiler dengan 5 perlakuan pakan dan 6 ulangan. Pada pengujian kualitas organoleptik panelis sebagai ulangan. Adapun perlakuan sebagai berikut :

$\mathrm{P0}=$ Bakso berbahan dasar daging ayam yang berasal dari ayam broiler yang diberi pakan tanpa suplementasi minyak ikan dan tepung purslane

P1 = Bakso berbahan dasar daging ayam yang berasal dari ayam broiler yang diberi pakan dengan suplementasi minyak ikan $1,5 \%$ dan tepung purslane $0 \%$

P2 = Bakso berbahan dasar daging ayam yang berasal dari ayam broiler yang diberi pakan dengan suplementasi minyak ikan $1,5 \%$ dan tepung purslane $6 \%$

P3 = Bakso berbahan dasar daging ayam yang berasal dari ayam broiler yang diberi pakan dengan suplementasi minyak ikan $1,5 \%$ dan tepung purslane $12 \%$

P4 = Bakso berbahan dasar daging ayam yang berasal dari ayam broiler yang diberi pakan dengan suplementasi minyak ikan $1,5 \%$ dan tepung purslane $18 \%$.

\section{Pengambilan Sampel}

Daging ayam bagian paha atas (thigh) yang berasal dari pemeliharaan selama 42 hari dengan suplementasi tepung purslane $0,6,12,18 \%$ dipisahkan dari tulang (deboning) dan daging paha atas (thigh) dibersihkan dari lemak yang menempel (trimming). Fillet daging dikemas kedap udara dan disimpan di dalam freezer pada suhu $-20^{\circ} \mathrm{C}$ sampai saat pembuatan bakso dilakukan. Daging dilakukan thawing dengan cara yaitu sampel daging didiamkan dalam udara terbuka pada suhu $27,5^{\circ} \mathrm{C}$ (Utami, 2007). Daging yang sudah kembali segar selanjutnya diolah menjadi bakso.

\section{Pembuatan Bakso}

Komposisi bakso adalah daging ayam broiler $75,78 \%$, tepung tapioka $8,87 \%$, garam $1,77 \%$, lada $0,22 \%$, bawang putih $1,77 \%$, putih telur $3,79 \%$, air es $7,58 \%$ dan MSG $0,22 \%$. Proses pembuatan bakso dilakukan dengan tahapan sebagai berikut:

a. Daging dicuci bersih, kemudian ditambah air es dan kemudian dihaluskan menggunakan blender selama 1 menit.

b. Daging dilumatkan lagi sambil ditambahkan tepung, telur dan bumbu.

c. Tepung tapioka ditambakan pada adonan sambil diaduk dan dilumatkan hingga diperoleh adonan yang homogen.

d. Adonan dicetak menjadi bulatan-bulatan yang siap direbus. Setiap bakso ditimbang seberat $25 \mathrm{~g}$. 
e. Bakso direbus dalam air mendidih hingga matang selama 7 menit.

f. Bakso yang matang ditandai dengan bakso mengapung ke permukaan. Bakso diangkat dan ditiriskan.

\section{Pengujian Kualitas Fisik}

Parameter kualitas fisik bakso yang diamati meliputi $\mathrm{pH}$ bakso, daya mengikat air, susut masak (cooking loss) dan keempukan. Nilai pH bakso diuji dengan mengambil $10 \mathrm{~g}$ sampel bakso dan dihaluskan. Hasil gilingan dimasukkan ke dalam gelas piala dan diencerkan dengan ditambahkan $100 \mathrm{ml}$ aquadest. Setelah itu di mixer dengan menggunakan blender selama 1 menit lalu diukur dengan $\mathrm{pH}$ meter yang sebelumnya dikalibrasi pada $\mathrm{pH} 4$ dan 7 (AOAC, 1984). Daya ikat air diukur menggunakan metode Hamm yaitu dengan menimbang sampel sebanyak 0,3 g sampel ditekan selama 5 menit menggunakan beban $35 \mathrm{~kg}$, selanjutnya daerah yang tertutup sampel bakso dan luas daerah basah disekitarnya ditandai dan diukur dengan planimeter untuk memperoleh nilai $\mathrm{mgH}_{2} \mathrm{O}$. Nilai $\mathrm{mgH}_{2} \mathrm{O}$ digunakan untuk menghitung kadar air bebas, dan nilai daya ikat air diperoleh dari selisih antara kadar air total dan kadar air bebas. Susut masak diperoleh dari perbedaan antara berat bakso sebelum dan sesudah dimasak, dinyatakan dalam persentase (Priyanto et al., 1995).

\section{Pengujian Kualitas Organoleptik}

Pengujian dilakukan oleh 35 orang panelis semi terlatih. Panelis direkrut dengan memberikan kuisioner untuk mendapatkan informasi-informasi yang terkait dengan konsumsi bakso daging ayam, baik dari adanya kemungkinan alergi terhadap daging ayam, tingkat kesukaan maupun seringnya mengonsumsi bakso daging ayam. Bakso yang sudah matang dipotong menjadi dua bagian dan dimasukkan kedalam plastic container kemudian disimpan pada freezer. Sebelum melakukan pengujian, bakso dihangatkan selama sekitar 15 menit. Setelah hangat bakso diletakkan pada container tertutup yang sudah diberi kode dengan 3 nomer acak (3-digit number). Sebelum dilakukan pengujian organoleptik panelis diberikan penjelasan tentang prosedur pengujian kualitas organoleptik bakso. Consent form dibagikan dan panelis diminta untuk menandatangani form tersebut. Pada pengujian quantitative descriptive analysis (QDA), panelis diberikan lembar kerja dan diminta untuk melakukan penilaian terhadap karakteristik bakso menggunakan $15-\mathrm{cm}$ line scale yang diberi tanda dari intensitas rendah sampai intensitas tinggi dari atribut yang dievaluasi. Pada pengujian tingkat kesukaan konsumen panelis menilai bakso menggunakan 9-point hedonic scale. Skoring yang digunakan dalam pengujian tinkat kesukaan konsumen panelis ditampilkan pada Tabel 1 . Penilaian atribut uji organoleptik ini meliputi warna, aroma, keempukan, tekstur, juiciness, rasa, cita rasa dan aftertaste. Setiap selesai pengujian satu sampel panelis diminta untuk minum air putih dan makan original crackers untuk menetralisir rasa dan panelis diberikan waktu istirahat 1 menit antara tiap dua sampel (Kartikasari et al., 2013).

\section{Analisa Data}

Semua data yang diperoleh dalam penelitian ini dianalisis menggunakan analisis sidik ragam atau Analysis of Variance (ANOVA) dengan aplikasi minitab 18 untuk mengetahui apakah terdapat pengaruh perlakuan penggunaan daging ayam broiler dengan suplementasi tepung purslane terhadap kualitas fisik dan organoleptik bakso daging ayam broiler. Uji lanjut dilakukan jika terdapat pengaruh yang nyata pada tiap rerata antar perlakuan dengan menggunakan uji Tukey's untuk mengetahui perbedaan rerata antar perlakuan (Steel dan Torrie, 1999).

\section{HASIL DAN PEMBAHASAN}

\section{Kualitas Fisik}

Hasil analisis statistik kualitas fisik bakso ditampilkan pada Tabel 2. Hasil menunjukkan penambahan minyak ikan 1,5\% (P2) dan kombinasi minyak ikan 1,5\% dengan tepung purslane 6 (P3), 12 (P4) dan $18 \%$ (P5) menunjukkan adanya hasil yang tidak berbeda nyata pada nilai $\mathrm{pH}$, daya ikat air/water holding capacity (DIA/WHC), susut masak dan keempukan bakso dibandingkan dengan nilai kualitas fisik tersebut pada bakso group P1 (tanpa minyak ikan dan tepung purslane). Rata-rata nilai DIA bakso daging ayam broiler hasil penelitian berkisar antara 35,81 $46,41 \%$. Hasil kualitas fisik bakso yang diperoleh ini sejalan dengan hasil analisa kualitas fisik daging ayam broiler dari masing-masing perlakuan suplementasi

Tabel 1. Penerimaan konsumen berdasarkan 9-point hedonic scale

\begin{tabular}{cl}
\hline \hline Skor Penerimaan Konsumen & \multicolumn{1}{c}{ Keterangan } \\
\hline 1 & Amat sangat tidak suka (extremely dislike) \\
2 & Sangat tidak suka (dislike very much) \\
3 & Tidak suka (dislike) \\
4 & Agak tidak suka (dislike slightly) \\
5 & Netral (neither like nor dislike) \\
6 & Agak suka(slightly) \\
7 & Suka (like) \\
8 & Sangat suka (like very much) \\
9 & Amat sangat suka (extremely like) \\
\hline
\end{tabular}


tepung purslane sebagai sumber asam lemak omega-3 yang menunjukkan tidak adanya perbedaan nyata. Hasil yang diperoleh ini sesuai dengan pendapat Soeparno (2009) yang menyatakan nilai daya ikat air daging ayam sekitar 20 - 60\%. Hasil ini juga sesuai dengan penelitian Wariyah dan Riyanto (2018) yang melaporkan bahwa DIA dan susut masak tidak berbeda antara kontrol dengan perlakuan pada bakso daging ayam ras dengan campuran gel lidah buaya. DIA yang tidak berbeda juga didukung oleh hasil penelitian Hartono (2013) yang mendapatkan bahwa nilai daya ikat air tidak berbeda dengan pemberian pakan sumber asam lemak omega-3 pada ayam broiler. Hasil yang diperoleh ini kemungkinan disebabkan oleh kadar protein pada pakan yang relatif sama, sehingga menghasilkan kadar protein daging yang tidak berbeda dan DIA juga tidak berbeda. Katikasari et al. (2001) melaporkan bahwa ternak yang mendapat pakan dengan kandungan protein yang rendah akan memiliki kandungan protein daging yang rendah pula. Hal ini didukung Soeparno (2009) yang menyatakan bahwa peningkatan kualitas protein dalam pakan dapat meningkatkan kadar protein dalam daging. Pendapat tersebut mengasumsikan bahwa kandungan protein dalam pakan memiliki hubungan yang berbanding lurus dengan kadar protein dalam daging. Oktaviana (2009) menambahkan bahwa DIA berbanding lurus dengan tingkat kadar protein dalam daging, yang berfungsi untuk mengikat air secara kimiawi. Daya ikat air berhubungan juga dengan pH (Lawrie, 2003), susut masak dan keempukan (Soeparno, 2009). Pada penelitian ini DIA tidak berbeda nyata, sehingga dimungkinkan susut masak, $\mathrm{pH}$ dan keempukan juga tidak berbeda nyata.

Kualitas keempukan juga menunjukkan tidak berbeda diantara perlakuan, Hal ini sesuai dengan pendapat Lestarini et al. (2015) bahwa keempukan bakso itik afkir segar dengan penambahan tepung kunyit dan tepung jahe tidak berbeda nyata. Nilai

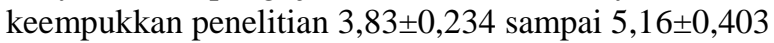
$\mathrm{mm} /$ menit. Pemberian sumber asam lemak pada pakan dideposisikan di dalam lemak intramuskular daging. Hal ini sesuai dengan pendapat Coetzee dan Hoffman (2002) yang melaporkan bahwa ransum yang mengandung asam lemak akan langsung diserap oleh hewan monogastrik tepatnya unggas dan didepositkan ke jaringan tubuhnya tanpa ada perubahan yang signifikan. Lemak inter dan intramuskular pada saat dimasak akan mengisi rongga-rongga diantara serabut otot dan jaringan konektif yang dapat meningkatkan tekstur (Wood et al., 2004; Moraes et al., 2016). Silva et al. (1999) menambahkan bahwa protein terlarut seperti kolagen dan miofibrillar pada $\mathrm{pH}$ 5,5 juga tidak berpengaruh terhadap keempukan.

Nilai $\mathrm{pH}$ bakso dalam penelitian ini $6,48 \pm 0,05$ sampai 6,58 $\pm 0,08$, nilai ini lebih tinggi dibanding nilai $\mathrm{pH}$ bakso ayam dengan kecambah kacang hijau (Hairunnisa et al., 2016) yaitu 5,15 - 5,70. Nilai susut masak bakso dalam penelitian berkisar antara $1,54 \pm 0,96$ sampai $2,76 \pm 0,39 \%$. Nilai ini lebih rendah dibanding penelitian Wariyah dan Rianto (2018) dengan nilai kisaran 2,41 $\pm 0,36$ sampai $3,79 \pm 0,19$ $\mathrm{g} / 100 \mathrm{~g}(\%)$ pada daging ayam ras dengan campuran gel lidah buaya. Perbedaaan nilai kualitas bakso dapat

Tabel 2. Pengujian fisik bakso daging paha atas ayam broiler umur 42

\begin{tabular}{lcccccc}
\hline \multirow{2}{*}{ Parameter } & \multicolumn{5}{c}{ Perlakuan } & \multirow{2}{*}{ Signifikasi } \\
\cline { 2 - 5 } & P1 & P2 & P3 & P4 & P5 & \multirow{2}{*}{ NS } \\
Susut Masak & $1,54 \pm 0,96$ & $1,94 \pm 0,73$ & $2,76 \pm 0,39$ & $1,55 \pm 0,66$ & $2,42 \pm 0,67$ & NS \\
pH & $6,48 \pm 0,05$ & $6,52 \pm 0,05$ & $6,54 \pm 0,06$ & $6,52 \pm 0,05$ & $6,58 \pm 0,08$ & NS \\
DIA (\%) & $44,13 \pm 7,81$ & $46,41 \pm 3,61$ & $40,76 \pm 9,54$ & $35,81 \pm 13,71$ & $39,43 \pm 6,25$ & \multirow{2}{*}{ NS } \\
Keempukan & $4,72 \pm 1,779$ & $4,22 \pm 0,588$ & $5,16 \pm 0,403$ & $4,58 \pm 0,662$ & $3,83 \pm 0,234$ & \\
mm/menit) & & & & & &
\end{tabular}

Keterangan: Daging ayam broiler yang diberi pakan tanpa penambahan tepung purslane dan minyak ikan (P1), mengandung minyak ikan 1,5\% dan tepung purslane $0 \%(\mathrm{P} 2)$, mengandung minyak ikan 1,5\% dan tepung purslane $6 \%(\mathrm{P} 3)$, mengandung minyak ikan $1,5 \%$ dan tepung purslane $12 \%(\mathrm{P} 4)$, mengandung minyak ikan 1,5\% dan tepung purslane $18 \%$ (P5), NS (Non Significant)

Tabel 3. Pengujian hedonik bakso daging paha atas ayam broiler umur 42

\begin{tabular}{lcccccc}
\hline \multirow{2}{*}{ Parameter } & \multicolumn{7}{c}{ Perlakuan } & \multirow{2}{*}{ Signifikasi } \\
\cline { 2 - 5 } & $\mathrm{P} 1$ & $\mathrm{P} 2$ & $\mathrm{P} 3$ & $\mathrm{P} 4$ & $\mathrm{P} 5$ & $\mathrm{NS}$ \\
Aroma & $6,17 \pm 1,04$ & $5,89 \pm 1,38$ & $5,97 \pm 1,42$ & $5,80 \pm 1,47$ & $5,66 \pm 1,43$ & $\mathrm{NS}$ \\
Warna & $6,29 \pm 1,07$ & $6,29 \pm 1,07$ & $6,46 \pm 0,92$ & $6,23 \pm 1,03$ & $6,40 \pm 0,98$ & $\mathrm{NS}$ \\
Rasa & $6,31 \pm 1,18$ & $5,91 \pm 1,44$ & $6,14 \pm 1,17$ & $5,57 \pm 1,38$ & $5,46 \pm 1,60$ & $\mathrm{NS}$ \\
Cita rasa & $6,34 \pm 1,11$ & $5,86 \pm 1,48$ & $6,03 \pm 1,04$ & $5,57 \pm 1,17$ & $5,57 \pm 1,46$ & $\mathrm{NS}$ \\
Keempukan & $6,23 \pm 1,06$ & $5,89 \pm 1,35$ & $6,00 \pm 1,26$ & $6,29 \pm 1,02$ & $6,14 \pm 1,09$ & $\mathrm{NS}$ \\
Tekstur & $6,43 \pm 0,85$ & $6,17 \pm 1,22$ & $6,20 \pm 1,21$ & $6,23 \pm 0,97$ & $6,00 \pm 0,97$ & $\mathrm{NS}$ \\
Overall & $6,46 \pm 1,09$ & $6,00 \pm 1,44$ & $6,26 \pm 1,01$ & $5,77 \pm 1,06$ & $5,83 \pm 1,32$ &
\end{tabular}

Keterangan: Daging ayam broiler yang diberi pakan tanpa penambahan tepung purslane dan minyak ikan (P1), mengandung minyak ikan $1,5 \%$ dan tepung purslane $0 \%(\mathrm{P} 2)$, mengandung minyak ikan 1,5\% dan tepung purslane $6 \%(\mathrm{P} 3)$, mengandung minyak ikan $1,5 \%$ dan tepung purslane $12 \%(\mathrm{P} 4)$, mengandung minyak ikan 1,5\% dan tepung purslane $18 \%$ (P5), NS (Non Significant) 
disebabkan karena jenis filler yang digunakan (Nullah et al., 2016). Miller (1994) menambahkan bahwa nilai $\mathrm{pH}$ bisa dipengaruhi oleh lemak karena sifat penghantaran panas dalam otot. Begitu pula untuk omega-3 PUFA, selain dipengaruhi oleh penghantaran panas juga dipengaruhi oleh stabilitas oksidatif, dan keduanya dapat mempertahankan kestabilan $\mathrm{pH}$ (Milicevic et al., 2015). Hal ini yang memungkinkan $\mathrm{pH}$ tidak berbeda nyata.

\section{Penerimaan Konsumen (Consumer Acceptance)}

Hasil analisis statistik tingkat kesukaan terhadap bakso daging ayam yang dibuat dari daging ayam dengan suplementasi tepung purslane pada pakan ditampilkan pada Tabel 3. Hasil menunjukkan penambahan minyak ikan $1,5 \%$ dan kombinasi minyak ikan 1,5\% dengan tepung purslane sampai $18 \%$ menunjukkan adanya hasil yang tidak berbeda nyata pada tingkat kesukaan konsumen yang meliputi aroma, warna, rasa, cita rasa, keempukan, tekstur dan overall. Tidak adanya perbedaan nyata terhadap tingkat kesukaan konsumen pada atribut aroma, rasa dan cita rasa bakso daging ayam pada penelitian ini kemungkinan juga disebabkan tanaman purslane tidak mengandung TMA yang menyebabkan off-odour atau off-flavour seperti pada daging ayam yang mendapat suplementasi asam lemak omega-3 yang bersumber dari laut. Hasil yang diperoleh ini didukung dari penelitian sebelumnya yang mendapatkan bahwa panelis tidak bisa membedakan tingkat kesukaan secara hedonik pada daging dada yang menggunakan ransum dengan penambahan sunflower seeds tinggi asam oleat (Hugo et al., 2009). Lebih lanjut Betti et al. (2009) menambahkan bahwa penggunaan flaxseeds sampai level $17 \%$ pada ransum tidak memengaruhi uji hedonik (tekstur, flavor, after taste, overall) pada daging dada ayam. Penggunaan bahan pakan sumber asam lemak omega-6 seperti sunflower oil dan sumber asam lemak omega-3 seperti linseed oil ataupun kombinasi keduanya juga dilaporkan oleh Panda et al. (2015), tidak menyebabkan terjadinya perbedaan pada uji kualitas hedonik pada daging ayam broiler.

\section{Kualitas Organoleptik}

Hasil analisis statistik kualitas organoleptik menggunakan uji QDA ditunjukkan pada Tabel 4. Hasil uji QDA menunjukkan penambahan minyak ikan 1,5\% dan kombinasi minyak ikan $1,5 \%$ dengan tepung purslane sampai level $18 \%$ menunjukkan adanya hasil yang tidak berbeda nyata pada warna, aroma, keempukkan, tekstur, juiceness, rasa, after taste dan cita rasa. Hasil penelitian ini didukung oleh hasil penelitian Kartikasari (2013) yang mendapatkan bahwa intensitas aroma daging yang mendapat pakan dengan penambahan blended vegetable oils yang mengandung canola oil dan flaxseed oil pada level $6 \%$ tidak berbeda dibandingkan daging kontrol. Demikian juga penelitian Azcona et al. (2008) mendapatkan bahwa penggunaan linseeds dan sunflower seeds yang tinggi asam oleat pada pakan ayam pedaging campera secara keseluruhan tidak berpengaruh terhadap uji sensorik (aroma, off aroma, warna, flavor, off flavor, keempukan) pada daging dada dan paha beku. Demikian juga penambahan sumber asam lemak n-3 PUFA dari soybean oil, mustard oil, linseed oil dan fish oil sampai $3 \%$ tidak memengaruhi uji sensorik pada daging ayam (Kalakuntlaa et al., 2017).

Penggunaan bahan pakan sumber asam lemak omega-3 dari laut seperti tepung ikan atau minyak ikan dilaporkan menghasilkan pengaruh negatif terhadap kualitas organoleptik daging seperti menurunkan aroma daging ayam karena adanya off-odour pada produk yang dihasilkan (Kolanowski and Laufenberg, 2006; Chekani-Azar et al., 2008). Timbulnya off-odour pada produk tersebut disebabkan oleh adanya trimetilamin (TMA) sebagai hasil dari reduksi trimetilamin oksida (TMAO) oleh bakteri atau kerja enzim, persenyawaan oksida tersebut umumnya terdapat dalam otot-otot ikan (Anjarsari, 2010). Tidak adanya perbedaan nyata terhadap intensitas aroma bakso daging ayam pada penelitian ini kemungkinan juga disebabkan tanaman purslane tidak mengandung TMA yang menyebabkan off-odour seperti pada sumber asam lemak omega-3 dari laut. Aroma daging dan produk olahan berkembang pada proses pemasakan, aroma tersebut

Tabel 4. Pengujian QDA bakso bakso daging paha atas ayam broiler umur 42

\begin{tabular}{lcccccc}
\hline \multirow{2}{*}{ Parameter } & \multicolumn{7}{c}{ Perlakuan } & \multirow{2}{*}{ Signifikasi } \\
\cline { 2 - 6 } & $\mathrm{P} 1$ & $\mathrm{P} 2$ & $\mathrm{P} 3$ & $\mathrm{P} 4$ & $\mathrm{P} 5$ & NS \\
Warna & $8,47 \pm 1,09$ & $8,49 \pm 0,90$ & $8,63 \pm 1,13$ & $8,40 \pm 1,17$ & $8,25 \pm 1,07$ & $\mathrm{NS}$ \\
Aroma & $8,36 \pm 1,33$ & $7,96 \pm 1,25$ & $8,33 \pm 1,51$ & $8,23 \pm 1,62$ & $8,32 \pm 1,55$ & $\mathrm{NS}$ \\
Keempukan & $7,98 \pm 1,31$ & $7,60 \pm 1,27$ & $7,65 \pm 1,39$ & $8,28 \pm 1,64$ & $8,01 \pm 1,14$ & $\mathrm{NS}$ \\
Tekstur & $6,81 \pm 1,80$ & $6,80 \pm 1,58$ & $6,84 \pm 1,30$ & $6,48 \pm 1,63$ & $6,52 \pm 1,45$ & $\mathrm{NS}$ \\
Juiceness & $7,35 \pm 1,50$ & $7,60 \pm 1,59$ & $7,38 \pm 1,35$ & $7,14 \pm 1,34$ & $7,31 \pm 1,03$ & $\mathrm{NS}$ \\
Rasa & $8,47 \pm 1,26$ & $8,49 \pm 1,41$ & $8,43 \pm 1,23$ & $8,28 \pm 1,34$ & $7,95 \pm 1,41$ & $\mathrm{NS}$ \\
After taste & $8,31 \pm 1,29$ & $8,24 \pm 1,20$ & $8,24 \pm 1,35$ & $8,03 \pm 1,33$ & $8,14 \pm 1,27$ & $\mathrm{NS}$ \\
Cita Rasa & $8,44 \pm 1,35$ & $8,40 \pm 1,23$ & $8,49 \pm 1,22$ & $8,20 \pm 1,30$ & $8,09 \pm 1,16$ &
\end{tabular}

Keterangan: Daging ayam broiler yang diberi pakan tanpa penambahan tepung purslane dan minyak ikan (P1), mengandung minyak ikan 1,5\% dan tepung purslane $0 \%(\mathrm{P} 2)$, mengandung minyak ikan $1,5 \%$ dan tepung purslane $6 \%$ (P3), mengandung minyak ikan $1,5 \%$ dan tepung purslane $12 \%(\mathrm{P} 4)$, mengandung minyak ikan 1,5\% dan tepung purslane 18\% (P5), NS (Non Significant) 
merupakan hasil interaksi antara asam amino, karbohidrat, lemak dan oksidasi termal serta degradasi tiamin. Menurut Northcutt (2009) lemak yang terdapat dalam daging merupakan senyawa kimia yang memberikan aroma khas pada daging ayam.

\section{KESIMPULAN}

Bakso yang mengandung daging ayam yang diberi pakan dengan suplementasi tepung purslane sampai level $18 \%$ tidak mempunyai efek negatif terhadap kualitas fisik dan organoleptik bakso, dan dapat diaplikasikan pada pembuatan bakso.

\section{UCAPAN TERIMA KASIH}

Penulis mengucapkan terima kasih kepada Program Studi Peternakan Universitas Sebelas Maret atas sarana yang telah diberikan dalam penelitian ini. Ucapan terima kasih dan penghargaan juga penulis sampaikan kepada Michael Adiputera atas dukungan dan bantuan dalam pelaksanaan jalannya penelitian ini.

\section{DAFTAR PUSTAKA}

Almatsier, S. 2006. Prinsip Dasar Ilmu Gizi. Gramedia Pustaka Utama. Jakarta.

Anjarsari, B. 2010. Pangan Hewani Fisiologi Pasca Mortem dan Teknologi. Graha Ilmu. Yogyakarta.

AOAC, 1984. Official methods of analysis. Association of Official. Agricultural Chemists. Washington DC.

Aydin, R. and I. Dogan. 2010. Fatty acid profile and cholesterol content of egg yolk from chickens fed diets supplemented with purslane (Portulaca oleracea L.) Journal of Science Food and Agriculture 90: 1759-1763.

Azconaa, J.O., P.T. Garciab, M.E. Cossuc, B.F. Iglesiasa, A. Picalloc, C. Perezb, C.I. Gallingerd, M.J. Schanga and Z.E. Caneta. 2008. Meat quality of Argentinean (Camperos) chicken enhanced inomega-3 and omega-9 fatty acids. Meat Science 79: 437-443.

Badan Standarisasi Nasional. 2014. Bakso ikan. SNI 7266-2014. Dewan Standarisasi Nasional. Jakarta.

Betti, M., B.L. Schneider, W.V. Wismer, V.L. Carney, M.J. Zuidhof and R.A. Renema. 2009. Omega-3enriched broiler meat: Functional properties, oxidative stability, and consumer acceptance. Poultry Science 88: 1085-1095.

Bou, R., F. Guardiola, A.C. Barroeta and R. Codony. 2005. Effect of dietary fat sources and zinc and selenium supplements on the composition and consumer acceptability of chicken meat. Poultry Science 84(7): 1129-1140.

Chekani-Azar, A., H.A. Shahria and Maheri. 2008. Omega-3 fatty acids enrichment and organoleptic charateristic of broiler meat. Asian Journal of Animal and Veterinary Advances 3(2): 62-69.

Coetzee, G.J.M. and L.C. Hoffman. 2002. Effect of various dietary $n-3 / n-6$ fatty acid ratios on the performance and body composition of broilers. Journal of Animal Science 32: 175-184.

Hairunnisa, O., E. Sulistyowati dan D. Suherman. 2016. Pemberian kecambah kacang hijau terhadap kualitas fisik dan uji organoleptik bakso ayam. Jurnal Sains Peternakan Indonesia 11: 39-47.

Hartono, E. 2013. Penggunaan Pakan Fungsional Terhadap Daya Ikat Air, Susut Masak dan Keempukan Daging Ayam Broiler. Skripsi. Fakultas Peternakan. Universitas Jenderal Soedirman. Purwokerto.

Hasanah, F., L. Nami dan A. Yuni. 2017. Pengendalian senyawa trimetilamin (TMA) dan amonia dalam pembuatan margarin dari minyak patin. Journal of Agro-based Industry 34: 72-80.

Hugo, A., S.P. Els, C. Bothma, F.H. de Witt, H.J. van der Merwe1 and M.D. Fair. 2009. Influence of dietary lipid sources on sensory characteristics of broiler meat. South African Journal of Animal Science 39(1): 12-14.

Irawan, D., P. Hariyadi dan H. Wijaya. 2003. The potency of krokot (portulaca oleracea) as functional food ingredients. Indonesian Food and Nutrition Progress 10(1).

Kalakuntlaa, S., N.K. Nagireddya, A.K. Pandab, N. Jatotha, R. Thirunaharia and R.R. Vangoor. 2017. Effect of dietary incorporation of $n-3$ polyunsaturated fatty acids richoil sources on fatty acid profile, keeping quality and sensory attributesof broiler chicken meat. Animal Nutrition 3: 386-391.

Kartikasari, L.R., Soeparno dan Setiyono. 2001. Komposisi kimia dan studi asam lemak daging dada ayam broler yang mendapat suplementasi metionin pada pakan berkadar protein rendah. Buletin Peternakan 25(1) : 33-39.

Kartikasari, L. R., R.J. Hughes, M.S. Geier, M. Makrides and R.A. Gibson. 2012. Comparison of omega-3 levels in two strains of broilers and layers fed high alpha-linolenic acid diets. In: proceedings of the $23^{\text {rd }}$ Annual Australian Poultry Science Symposium: 19-22 ${ }^{\text {nd }}$ February 2012. Sydney, Australia.

Kartikasari, L.R. 2013. Omega-3 long chain polyunsaturated fatty acid ( $n-3$ lcpufa) levels in chicken products following consumption of alpha-linolenic acid enriched diets. Ph. D. Thesis. University of Adelaide. Adelaide, Australia.

Kartikasari, L.R., B.S. Hertanto, I. Santoso dan A.M.P. Nuhriawangsa. 2018. Kualitas fisik daging ayam broiler yang diberi pakan berbasis jagung dan kedelai dengan suplementasi tepung purslane $(P$ oleracea). Jurnal Teknologi Pangan 12.

Kolanowski. W. and G. Laufenberg. 2006. Enrichment 
of food products with polyunsaturated fatty acids by fish oil addition. European Food Research and Technology 222: 472-477.

Lawrie, R.A. 2003. Meat Science. 5th ed. The Avi Publishing Company. Incorporated. Westport. Connecticut.

Lestarini, I.N., N. Anggarawati, A.M.P. Nuhriawangsa dan R. Dewanti. 2015. Manfaat Penambahan Tepung Kunyit (Curcuma domestica Val.) dan Tepung Jahe (Zingiber officinale) terhadap Kualitas Bakso Itik Afkir dengan Lama Penyimpanan yang Berbeda. Buletin Peternakan 39(1): 9-16.

Lishianawati, T.U. 2017. Pengaruh Penggunaan Tepung Purslane (Portulaca oleracea) dalam Ransum terhadap Kualitas Kimia Kuning Telur Ayam Petelur. Skripsi. Fakultas Pertanian. Universitas Sebelas Maret. Surakarta.

Miller, R.K. 1989. Quality characteristics. In: Kinsman, D.M., A.W. Kotula and B.C. Breidenstein, editor, Musle Foods Meat Poultry and Seafood Technology. Chapman \& Hall. New York.

Milicevic, D., D. Trbovic, Z. Petrovic, B.J. Strajn, I. Nastasijevic and V. Koricanac. 2015. Physicochemical and functional properties of chicken meat. Procedia Food Science 5: 191-194.

Moraes, P.O., L. Novelini, J.S. Lemes, M.A.Z. Santos, C.M.P. Pereira and E.G. Xavier. 2016. Carcass yield, sensory analysis and meat quality of broilers fed canola meal. Acta Scientiarum Animal Sciences 38: 267-274.

Northcutt, J.K. 2009. Factors affecting poultry meat quality. Departement of Poultry Science. The University of Georgia (Bulletin 1157).

Nullah, L.N., H. Hafid dan A. Indi. 2016. Efek bahan filler lokal terhadap kualitas fisik dan kimia bakso ayam petelur afkir. Jurnal Ilmu dan Teknologi Peternakan 3(2): 58-63.

Oktaviana, D. 2009. Pengaruh Pemberian Ampas
Virgin Coconut Oil dalam Ransum terhadap Performan, Produksi Karkas. Perlemakan, Antibodi dan Mikroskopik Otot Serta Organ Pencernaan Ayam Broiler. Tesis. Fakultas Peternakan. Universitas Gadjah Mada. Yogyakarta.

Panda, A.K., K. Sridhar, G. Lavanya, B. Prakash, S.V. R. Rao and M.V.L.N. Raju. 2015. Growth performance, carcass characteristics, fatty acid composition and sensoryattributes of meat of broiler chickens fed diet incorporated with linseed oil. Indian Journal of Animal Sciences 85(12): 1354-1357.

Priyanto, R., J. Fisher and P.R. Kale. 1995. Some aspect of meat research. Materi Workshop. Universitas Nusa Cendana. Kupang.

Raharjo, S.S. 2011. Kandungan Omega 3. Erlangga. Surabaya.

Silva, J.A., L. Patarata and C. Martins. 1999. Influence of ultimate $\mathrm{pH}$ on bovine meat tenderness during aging. Meat Science 52(4): 453-459.

Soeparno, 2009. Ilmu dan Teknologi Daging. Cetakan ke-5. Gadjah Mada University Press. Yogyakarta.

Steel, R.G.D. and J.H. Torrie. 1995. Prinsip dan Prosedur Statistika. (diterjemahkan oleh Bambang Sumantri). Gramedia Pustaka Utama. Jakarta.

Utami, 2007. Pengaruh metode thawing terhadap kualitas fisik dan mikrostruktular daging beku sapi perah peranakan ongole jantan dewasa. Bulletin Peternakan.

Wariyah, C. dan Riyanto. 2018. Efek antioksidatif dan akseptabilitas bakso daging ayam ras dengan penambahan gel lidah buaya. Agritech 8(2): 125132.

Wood, J.D., M. Emser, A.V. Fisher, G.R. Nute, P.R. Sheard, R.I. Reichardson, S.I. Hughes and M. Enser. 2004. Effects of fatty acids on meat quality: A review. Meat Science 78:343-358. 